\title{
MICROSTRUCTURAL CHARACTERISATION OF HIGH TEMPERATURE OXIDATION OF NICKEL BASE SUPERALLOY RR1000 AND THE EFFECT OF SHOT-PEENING
}

\author{
S. Cruchley ${ }^{1}$, M.P. Taylor ${ }^{1}$, H.E. Evans ${ }^{1}$, P. Bowen ${ }^{1}$, M. C. Hardy ${ }^{2}$ and S. Stekovic ${ }^{2}$ \\ ${ }^{1}$ School of Metallurgy and Materials, University of Birmingham, UK \\ ${ }^{2}$ Rolls-Royce plc., Derby, UK
}

Keywords: Oxidation, Ni-based superalloy, RR1000, shot-peening

\begin{abstract}
High temperature oxidation resistance is becoming increasingly important to component life as operating temperatures increase. Additionally, shot-peening is used to help extend the service life of high-duty components through inducing compressive stresses in the surface. The effect of shot-peening on oxidation resistance has not been examined in detail, at least on recent high-strength turbine disc alloys such as RR1000. In this study, oxidation of a coarse-grained variant of RR1000, with and without shot peening, has been characterised over a range of temperatures $\left(700-800^{\circ} \mathrm{C}\right)$ for periods of time extending to 2000 hours. Microstructural characterisation of the oxide and underlying material was performed using a number of techniques. A duplex surface oxide, comprised largely of $\mathrm{Cr}_{2} \mathrm{O}_{3}$ covered by a thin top layer of $\mathrm{TiO}_{2}$ was recorded in both surface conditions. Beneath this surface oxide was an alumina internal oxide, with the shot-peened condition exhibiting more numerous penetrations. The oxide growth kinetics in both alloy conditions were similar.
\end{abstract}

\section{Introduction}

There is a significant amount of market pressure on aero-engine manufacturers to produce more efficient gas turbine engines with higher specific fuel consumptions and reduced $\mathrm{NO}_{\mathrm{x}}$ and $\mathrm{CO}_{2}$ emissions, as well as reducing overall noise levels through the ACARE 2020 directive [1]. ACARE 2020 is a European target with an objective to reduce $\mathrm{CO}_{2}$ emissions by $50 \%$ per passenger kilometre, to reduce noise by $50 \%$ and $\mathrm{NO}_{\mathrm{x}}$ emissions by $80 \%$. These will apply, from a 2000 baseline, by 2020 with further cuts required by the year 2050. In order for these challenging targets to be met, it necessitates the raising of compressor discharge temperatures and turbine entry temperatures. It follows that the high pressure (HP) disc rotors must be able to withstand higher temperatures and stresses. High temperature oxidation is therefore becoming increasingly important in the HP disc rotors, since oxidation has the potential to reduce component lives. Several proposed mechanisms have been given for this reduction in life, the main one being grain boundary oxidation at and ahead of the crack tip [2-5]. It has been established that shot-peening can extend the service life of critical components through inducing compressive stresses in the surface and, thereby, improving fatigue crack resistance [6]. This is the condition that HP disc rotors enter service. Earlier research has quantified the oxidation resistance of several different wrought Ni-base superalloys without the presence of shot-peening, detailing the oxidation kinetics and internal damage [7-15]. The effect of applied stress and the effect of surface roughness have also been investigated and have been shown to increase oxidation rates $[8,16]$. The composition of the typical oxide formed on a Ni-base superalloy at intermediate temperatures, while affected by the composition of the alloy, is generally a chromium-rich oxide, with a surface layer of rutile and an internal oxide of alumina [7]. Little of this work has shown the effect of shot-peening on the oxidation of these $\mathrm{Ni}$ base superalloys. On a Fe-Ni-base alloy, Incoloy $800 \mathrm{H}$, under cyclic oxidation conditions at $850^{\circ} \mathrm{C}$ in laboratory air, shotpeening improved the oxidation resistance by enhanced chromium diffusivity to produce the early formation of chromium-rich oxides $[17,18]$. The same beneficial effect has also been reported in chromia-forming steels [19]. This effect was seen in steels with high chromium contents $(\sim 18 \% \mathrm{wt})$ at all temperatures tested but for low chromium $(<12 \% \mathrm{wt})$ contents the effect was only observed above $700^{\circ} \mathrm{C}$. Noting that in relative terms the chromium content of RR1000, is relatively low at $15 \%$ wt. (16.5\% at.), Table I, shot-peening could be expected to have a similar effect in RR1000. The aim of this paper is to present the initial results of the effects of shot-peening on the high temperature oxidation of the Ni-base superalloy, RR1000.

\section{Experimental Method}

\section{Material and Sample Preparation}

A coarse-grained (CG) variant of Ni-base superalloy RR1000 was provided by Rolls-Royce plc. The nominal composition is stated it Table I and the alloy, typically, has a grain size of $30-50 \mu \mathrm{m}$. The material was prepared in two conditions.

Table I. Nominal Composition of CG RR1000 in Atomic and Weight \%

\begin{tabular}{lccccccccccc} 
& Ni & $\mathbf{C o}$ & $\mathbf{C r}$ & $\mathbf{M o}$ & $\mathbf{T i}$ & $\mathbf{A l}$ & $\mathbf{T a}$ & $\mathbf{H f}$ & $\mathbf{Z r}$ & $\mathbf{C}$ & $\mathbf{B}$ \\
\hline Weight \% & Bal & 18.5 & 15.0 & 5.0 & 3.6 & 3.0 & 2.0 & 0.5 & 0.06 & 0.02 & 0.03 \\
Atomic \% & Bal & 17.9 & 16.5 & 3.0 & 4.3 & 6.35 & 0.63 & 0.16 & 0.04 & 0.14 & 0.10 \\
\hline
\end{tabular}


The first condition was the un-peened alloy where samples were cut, ground and chamfered before being polished to a $6 \mu \mathrm{m}$ finish, using conventional preparation methods to a size of $10 \mathrm{~mm} \mathrm{x}$ $5 \mathrm{~mm} \times 2 \mathrm{~mm}$. The second condition was the shot-peened condition in which the same coarse-grained variant was cut $(20 \mathrm{~mm} \times 10 \mathrm{~mm} \times 2 \mathrm{~mm})$, chamfered and ground to a 1200 grit finish before undergoing shot-peening using the following conditions: $110 \mathrm{H}$ steel shot, $6-8$ Almen and $200 \%$ coverage.

\section{Isothermal Oxidation Testing}

Isothermal oxidation testing was conducted at $700^{\circ} \mathrm{C}, 750^{\circ} \mathrm{C}$ and $800^{\circ} \mathrm{C}$ for times ranging from 24 hours to 2000 hours in laboratory air. Sample dimensions were accurately measured using a micrometer before the specimens were cleaned and degreased in ethanol using an ultrasonic agitator for a period of 5 minutes, dried and weighed. The samples were weighed three times using a sensitive micro-balance $\left(1 \times 10^{-5} \mathrm{~g}\right)$. The balance was calibrated before every set of measurements using its internal calibration function. Samples were placed into open alumina boats before being inserted into single zone tube furnaces. The furnaces were calibrated to $+/-1^{\circ} \mathrm{C}$ using an N-type thermocouple. Samples were periodically taken out of the furnace and alumina boats (500 hour intervals) and weighed to record the net mass gain. Multiple samples were exposed at most (but not all) times and temperatures for both conditions; the error bars shown in the figures correspond to \pm 1 standard deviation.

\section{Characterisation of Oxidised and Unoxidised Material}

Characterisation of the samples was performed both prior to and after oxidation using a number of techniques. Confocal microscopy was performed on an Olympus Lext OLS 3100, with a TS-150 table stabilisation unit and was used to record the surface roughness profiles $\left(S_{a}, R_{a}, R_{c}\right)$ of the samples, over an area of $480 \times 640 \mu \mathrm{m}$. The manufacturer's reported vertical resolution for this equipment was $0.01 \mu \mathrm{m}$. The $\mathrm{R}_{\mathrm{a}}$ measurements were checked using a Taylor Hobson Form Talysurf, (with vertical resolution of $10 \mathrm{~nm}$ ). The measurement was performed using a stylus angle of $60^{\circ}$, a stylus tip length of $2 \mu \mathrm{m}$ and an evaluation length of $4.0 \mathrm{~mm}$. Micro-hardness was performed on specimen cross-sections using an automated Struers Durascan microhardness machine (Vickers hardness, with a $0.3 \mathrm{~kg}$ load). The indents were positioned at $0.01 \mathrm{~mm}$ intervals starting from $0.04 \mathrm{~mm}$ from the surface to a depth of $0.1 \mathrm{~mm}$ and then at $0.02 \mathrm{~mm}$ intervals to a total depth of $0.5 \mathrm{~mm}$. This was performed three times in a diagonal pattern to quantify the extent of the shotpeened affected zone. After oxidation testing, samples were carefully prepared for cross-sectional analysis in order to preserve the oxide layer. The samples were gold coated, Ni-plated in a Watts bath and mounted in low viscosity and low shrinkage resin using vacuum impregnation. Samples were then conventionally ground and polished finishing in a colloidal silica sol. Analysis was performed using a JEOL 7000F FEG Scanning Electron Microscope (SEM) for characterisation of oxide morphology and composition. Chemical etching was performed on cross-sectioned samples using two different etches (compositions in Table II [20, 21]); Kalling's etch was used for grain structure and a selective $\gamma^{\prime}$ etchant for $\gamma^{\prime}$ volume fraction and denuded zones. Samples were submersed in the etchant for 5-10 seconds and 60 seconds, respectively. Evaluation of the volume fraction of secondary $\gamma^{\prime}$ was performed on six images using Image $\mathbf{J}$ software.
Table II. Composition of Two Chemical Etchants.

\begin{tabular}{lrcc} 
& \multicolumn{2}{c}{ Gamma Prime $\left(\gamma^{\prime}\right)$} & Kallings Etch \\
Etch & \\
\hline Chemical & Part 1 & & \\
composition & - & $150 \mathrm{ml} \mathrm{H} \mathrm{O}_{2}$, & $-100 \mathrm{ml}$ ethanol \\
& - & $150 \mathrm{ml} \mathrm{HCl}$ & $96 \%$ \\
& - & $2.5 \mathrm{~g} \mathrm{MoO}_{3}$ & $-100 \mathrm{ml}$ \\
& Part 2 & & hydrochloric acid \\
& - & $15 \mathrm{ml} \mathrm{HNO}_{3}$ & $32 \%$ \\
& - & $25 \mathrm{ml} \mathrm{H}_{2} \mathrm{O}$ & -5 g copper (II) \\
& - & $30 \mathrm{ml} \mathrm{Part} \mathrm{1.}$ & chloride \\
\hline
\end{tabular}

\section{Results and Discussion}

\section{Effect of Shot-Peening on Microstructure}

Figure 1 show that shot-peening produced a variation in hardness across the specimen cross-section. The hardness of the specimen surface was raised significantly and extended to a depth of around $140-150 \mu \mathrm{m}$ from the surface. From the error bars it can be seen that there is a significant amount of scatter which is associated with the discrete $\gamma / \gamma^{\prime}$ microstructure. The depth of this hardness affected zone compares well with previous research performed on the Ni-base superalloy $720 \mathrm{Li}$ where an affected depth of $140 \mu \mathrm{m}$ was found [18]

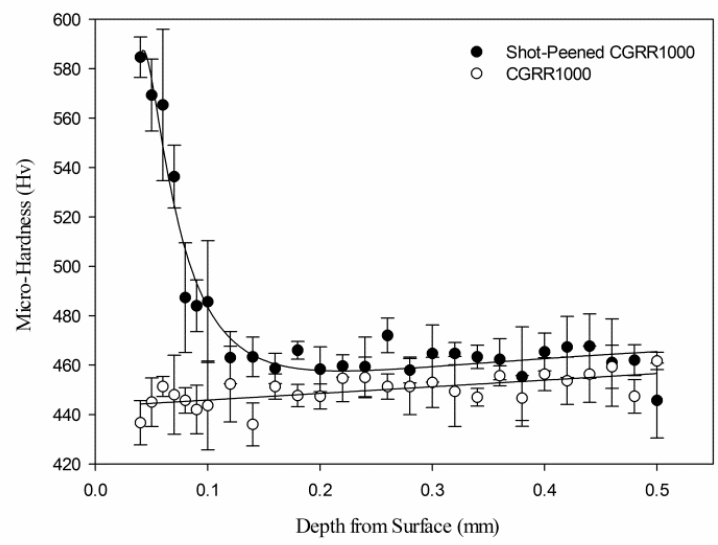

Figure 1. A micro-hardness trace of sectioned CG RR1000, with and without shot-peening ( \pm 1 standard deviation).

Figure 2 shows the $\gamma^{\prime}$ morphology in the surface regions of a cross-section from both specimen conditions. A distinct narrow zone at the surface of the shot-peened cross-section containing distorted $\gamma^{\prime}$ particles is apparent. This shows that shot-peening severely affects the microstructure in the outer $1-2 \mu \mathrm{m}$ zone but the Hv depth profile shows a significant effect much further into the alloy. The distortion of the surface regions is likely to be the reason why they could not be characterized using Electron Backscatter Diffraction (EBSD) [18]. Table III, shows there was no significant difference in secondary $\gamma^{\prime}$ volume fraction between either specimen conditions or between the surface and centre regions of these specimens 

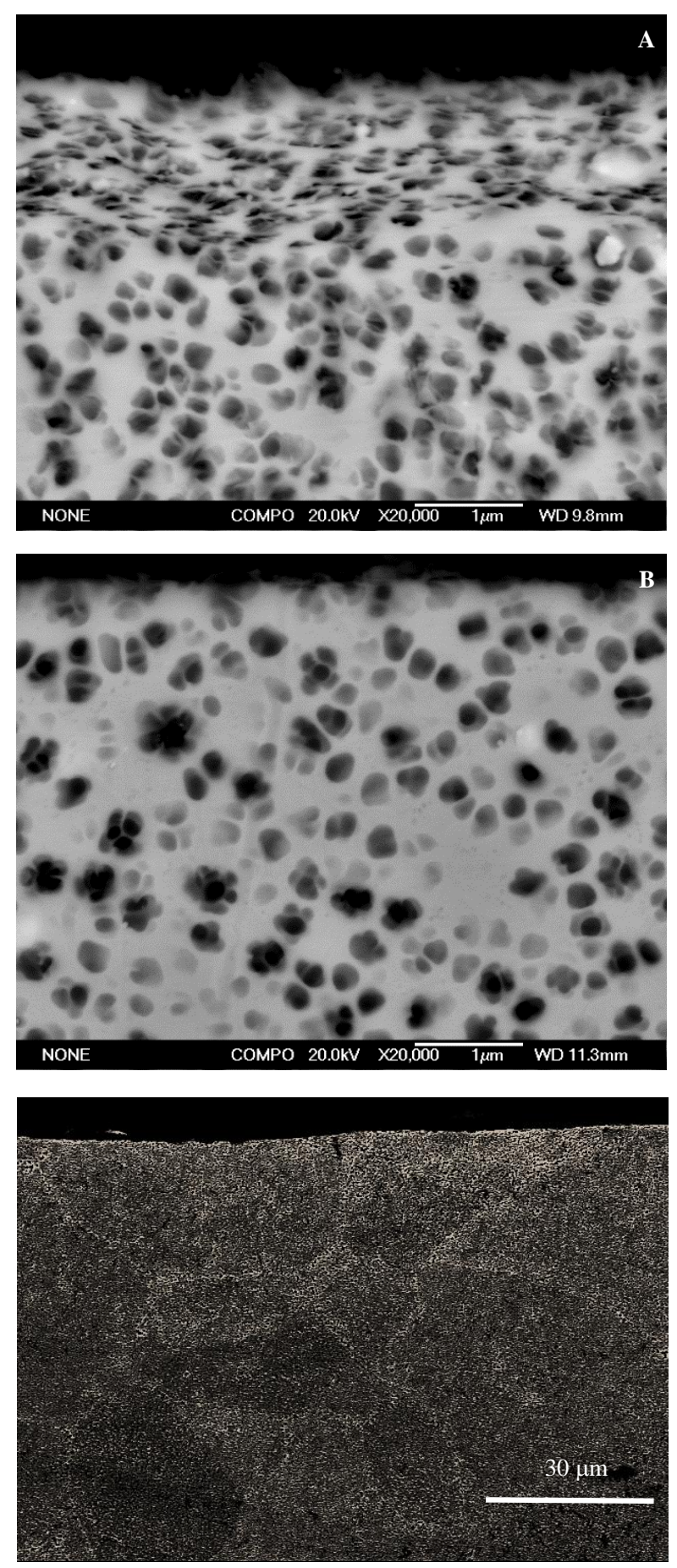

Figure 2. SEM images of sections through etched samples of CG RR1000 showing a) the secondary $\gamma^{\prime}$ precipitates in the shotpeened condition and b) un-peened condition, using a selective $\gamma^{\prime}$ prime etchant, and c) the grain structure of the shot-peened condition using Kallings Etchant (Table II).
Table III. Volume Fraction of Secondary $\gamma^{\prime}$ in a CG Variant of RR1000, With and Without Shot-Peening, in the Surface and Centre Regions of a Cross-Sectioned Sample.

\begin{tabular}{lcc} 
& CG RR1000 & $\begin{array}{c}\text { Shot-Peened CG } \\
\text { RR1000 }\end{array}$ \\
\hline Surface & $40 \%( \pm 3)$ & $46 \%( \pm 5)$ \\
Centre & $41 \%( \pm 3)$ & $46 \%( \pm 5)$ \\
\hline
\end{tabular}

\section{Estimating True Surface Area}

Shot-peening has a significant effect on the surface of RR1000 which can be seen by the significantly rougher surface, with much larger $S_{a}, R_{a}$ and $R_{c}$ values (Table IV). These surface roughness measurements, again as with the hardness affected zone, compare well with those found using the same shot-peening conditions in Udimet 720Li [18]. A good correlation was found between the measurements performed on the shot-peened and as-polished surfaces using the confocal microscope (Table IV) and the Talysurf technique $\left(\mathrm{R}_{\mathrm{a}}=1.42 \mu \mathrm{m}, 0.01 \mu \mathrm{m}\right.$ respectively).

Table IV. Confocal Microscope Surface Roughness Measurements of CG RR1000, $\mu \mathrm{m}$ ( \pm 1 standard deviation).

\begin{tabular}{ccc} 
& CG RR1000 & $\begin{array}{l}\text { Shot-peened } \\
\text { CG RR1000 }\end{array}$ \\
\hline $\mathbf{S}_{\mathbf{a}}$ & $0.43( \pm 0.16)$ & $1.57( \pm 0.01)$ \\
$\mathbf{R}_{\mathbf{a}}$ & $0.31( \pm 0.12)$ & $1.48( \pm 0.18)$ \\
$\mathbf{R}_{\mathbf{c}}$ & $1.00( \pm 0.46)$ & $3.81( \pm 0.64)$ \\
\hline
\end{tabular}

The oxidation reaction is usually described by mass gain per unit specimen area. Conventionally, this is taken as the geometric area of the specimen but where appreciable surface roughness exists (e.g. after shot-peening) it is desirable to make an estimate of the effective surface area and use this in the calculation of the specific mass gain. This is important in allowing the accurate determination of the oxidation kinetics of shot-peened CG RR1000. As a first approach, the actual surface area of the shotpeened samples was calculated by assuming the surface roughness followed a sinusoidal profile. The effective increase in line length was then estimated by calculating the arc length using the roughness data obtained earlier. This arc length is given by equation (1) below

$l_{c}=\int_{0}^{\omega} \sqrt{1+\left(\frac{d y}{d x}\right)^{2}} \mathrm{dx}$

where $l_{c}$ is the length of the curve, $x$ is the linear coordinate between 0 and the wavelength, $\omega$, and y is given by:-

$y=A \sin \frac{2 \pi x}{\omega}$

where $\mathrm{A}$ is the amplitude (half $\mathrm{Rc}$ of $3.81 \mu \mathrm{m}$ ), $\omega$ is the wavelength $(24 \mu \mathrm{m})$. This gives:- 
$y=1.9 \sin \frac{2 \pi x}{24}$

Differentiating this gives:-

$\mathrm{dy} / \mathrm{dx}=0.4974 \cos \frac{\pi x}{12}$

Inputting equation (4) into Equation 1 then gives:

$l_{c}=\int_{0}^{24} \sqrt{1+\left(0.4974 \cos \left(\frac{\pi x}{12}\right)\right)^{2}} \mathrm{dx}$

This integral was evaluated numerically using software available at www.wolframalpha.com/input/?i=integral to give a $5.9 \%$ increase in length over the roughness wavelength. This corresponds to an increase in surface area of $12.2 \%$. This increase in surface area was then applied to the geometric surface area recorded on the shot-peened samples.

\section{Isothermal Oxidation}

The oxidation kinetics were described by the following equation:

$$
\left(\frac{\Delta m}{A}\right)^{n}=k_{n} t
$$

where $\left(\frac{m}{A}\right)$ is the mass change/true surface area $\left(\mathrm{mg} \cdot \mathrm{cm}^{-2}\right)$, exposure time ( $t$ ) in seconds and $k_{n}$ is the rate constant. The value of $\mathrm{n}$ was determined by plotting $\log \left(\frac{m}{A}\right)$ against $\log \mathrm{t}$ and gave values for $\mathrm{n}$ at each temperature for both specimen conditions. From Table V, it can be seen that parabolic behaviour can be reasonably assumed $(\mathrm{n}=2)$ for this alloy at all temperatures and for both surface conditions, to give a parabolic rate constant $\left(\mathrm{k}_{\mathrm{p}}\right)$ in $\mathrm{mg}^{2} \cdot \mathrm{cm}^{-4} \cdot \mathrm{s}^{-1}$.

Table V. Oxidation kinetics n values for CG RR1000 with and without shot-peening. Parabolic kinetics $(\mathrm{n}=2)$ are a reasonable approximation.

\begin{tabular}{ccc} 
& CG RR1000 & $\begin{array}{c}\text { Shot-peened } \\
\text { CG RR1000 }\end{array}$ \\
\hline $\mathbf{7 0 0}^{\circ} \mathbf{C}$ & 1.9 & 2.0 \\
$\mathbf{7 5 0}^{\circ} \mathbf{C}$ & 2.2 & 2.2 \\
$\mathbf{8 0 0}^{\circ} \mathbf{C}$ & 2.0 & 2.1 \\
\hline
\end{tabular}

Using this approach, the oxidation data were plotted according to Equation 6, with $\mathrm{n}=2$, Figure 3 . This shows that shot-peening has no effect on the reaction rate at $800^{\circ} \mathrm{C}$ but has a detrimental effect at both $750^{\circ} \mathrm{C}$ and $700^{\circ} \mathrm{C}$. The $\mathrm{k}_{\mathrm{p}}$ values for each of these temperatures and conditions are given in Table VI, along with values for the Fine Grained (FG) variant of RR1000 and a pure chromia forming steel. The values for both variants of RR1000 are comparable but are much higher than those for pure chromia formation, indicating that other elements are oxidising in the superalloys. It has previously been shown that shot-peening can have a beneficial effect on the oxidation kinetics [17-19]. This was attributed to the early formation of chromia. Shot-peening of CG RR1000 does provide short-circuit paths for diffusion of chromium, but also for other alloy constituents, such as Ti accounting for the higher mass gains. Thus, shot-peened
CG RR1000 forms a semi-protective layer of $\mathrm{Cr}_{2} \mathrm{O}_{3}$, as does the un-peened sample, and the potential strength of shot-peening are not realised.

$7^{\circ 0}{ }^{\circ} \mathrm{C}$

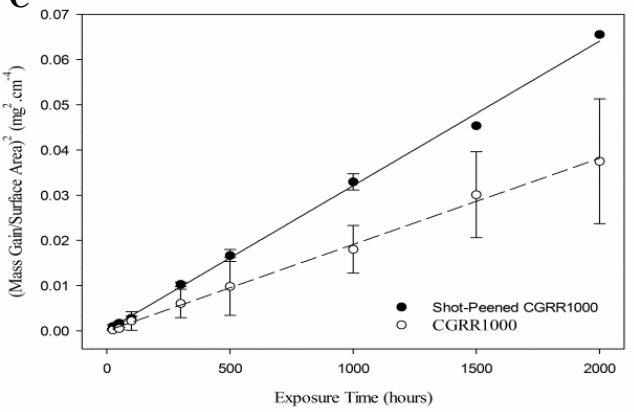

$7^{750} \mathrm{C}$

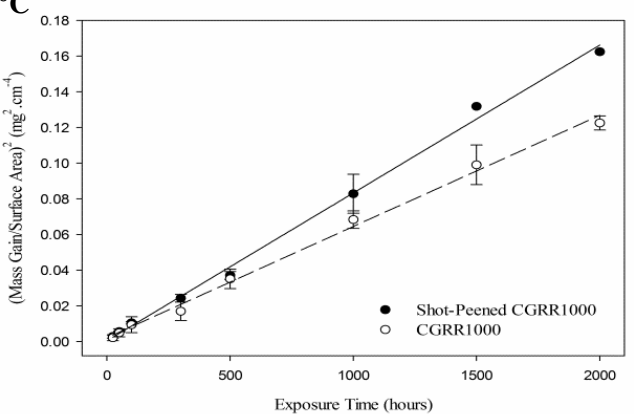

$800^{\circ} \mathrm{C}$

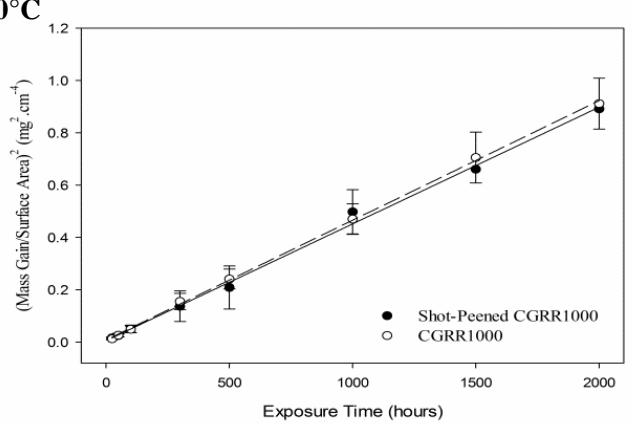

Figure 3. $\mathrm{k}_{\mathrm{p}}$ graphs, of CG RR1000 with and without shotpeening at $700^{\circ} \mathrm{C}, 750^{\circ} \mathrm{C}$ and $800^{\circ} \mathrm{C}( \pm 1$ standard deviation $)$.

An Arrhenius equation (Equation 7) was used to calculate the activation energy of oxide formation for both specimen conditions.

$$
k_{p}=k_{o} \exp \left(\frac{-Q}{R T}\right)
$$

where $\mathrm{k}_{\mathrm{o}}$ is a constant, $\mathrm{Q}$ is the activation energy for oxide growth $\left(\mathrm{J} . \mathrm{mol}^{-1}\right), \mathrm{R}$ is the gas constant, $\mathrm{T}$ is the exposure temperature $(\mathrm{K})$. Tentative values, based on three temperatures, of the activation energies for CG RR1000 with and without shot-peening are given in Table VII and shown to be similar to published values on other relevant Ni-based superalloys. It is worth noting that no spallation was seen at any temperature and time tested in this investigation. 
Table VI. Parabolic Rate Constants $\left(\mathrm{mg}^{2} \cdot \mathrm{cm}^{-4} \mathrm{~s}^{-1}\right)$ for CG RR100 with and without Shot-Peening, including Fine Grained RR1000 and a Pure Chromia Forming Steel.

\begin{tabular}{rcccc} 
& CG RR1000 & $\begin{array}{c}\text { Shot-peened CG } \\
\text { RR1000 }\end{array}$ & FG RR1000 $^{[14]}$ & $\begin{array}{c}\text { Pure chromia }^{[22]} \\
\text { formation }\end{array}$ \\
\hline $\mathbf{7 0 0}^{\circ} \mathbf{C}$ & $3.43 \times 10^{-9}$ & $8.88 \times 10^{-9}$ & $3.89 \times 10^{-9}$ & $7.99 \times 10^{-10}$ \\
$\mathbf{7 5 0}^{\circ} \mathbf{C}$ & $1.73 \times 10^{-8}$ & $2.39 \times 10^{-8}$ & $3.79 \times 10^{-8}$ & $3.79 \times 10^{-9}$ \\
$\mathbf{8 0 0}^{\circ} \mathbf{C}$ & $1.27 \times 10^{-7}$ & $1.24 \times 10^{-7}$ & $2.33 \times 10^{-7}$ & $1.56 \times 10^{-8}$ \\
\hline
\end{tabular}

Table VII A Comparison of Activation Energies of Oxide formation in CG RR100 with and without Shot-Peening, with other similar Nibase superalloys.

\begin{tabular}{|c|c|c|c|c|c|c|}
\hline & CG RR1000 & $\begin{array}{l}\text { Shot-peened } \\
\text { CG RR1000 }\end{array}$ & FG RR1000 & Udimet720 ${ }^{[7]}$ & Astroloy ${ }^{[7]}$ & Waspaloy $^{[7]}$ \\
\hline $\begin{array}{l}\text { Activation } \\
\text { energy }\end{array}$ & $303 \mathrm{~kJ} \cdot \mathrm{mol}^{-1}$ & $223 \mathrm{~kJ} \cdot \mathrm{mol}^{-1}$ & $270 \mathrm{~kJ} \cdot \mathrm{mol}^{-1}$ & $250 \mathrm{~kJ} \cdot \mathrm{mol}^{-1}$ & $270 \mathrm{~kJ} \cdot \mathrm{mol}^{-1}$ & $300 \mathrm{~kJ}^{\mathrm{mol}}{ }^{-1}$ \\
\hline
\end{tabular}
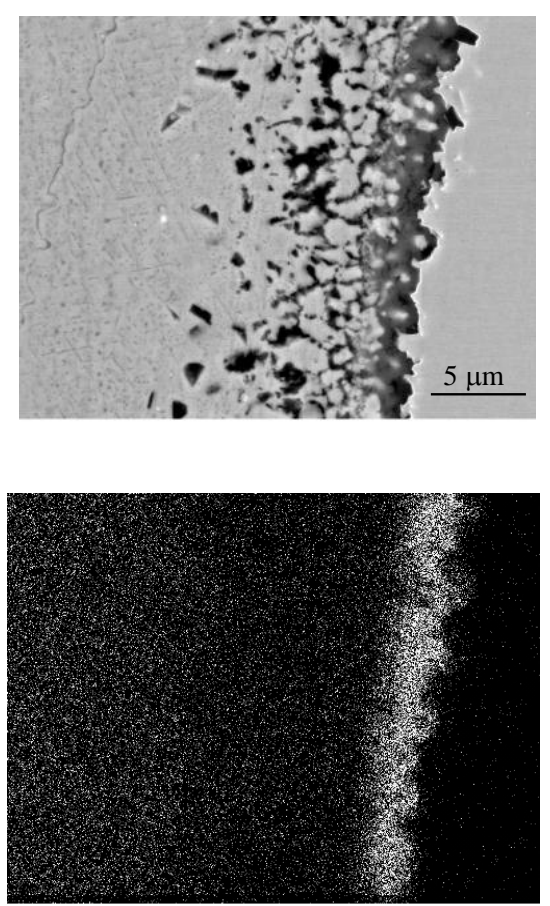

$\mathrm{Cr}$

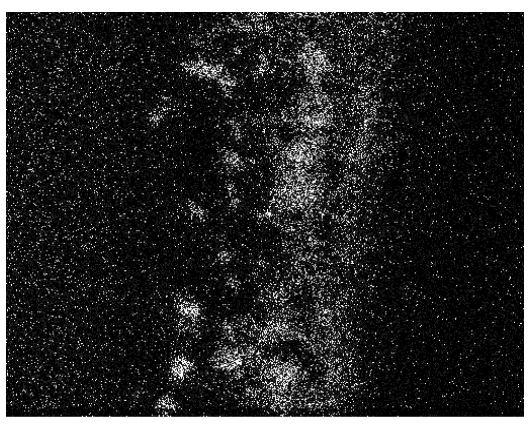

$\mathrm{Al}$

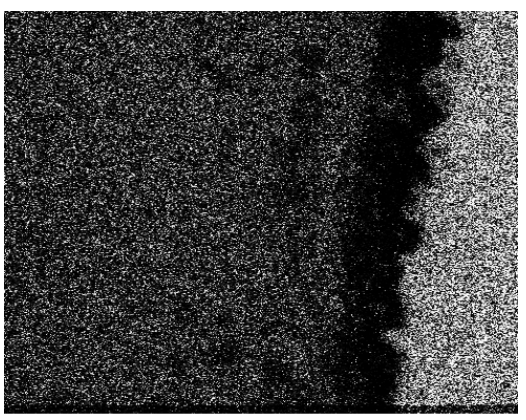

$\mathrm{Ni}$

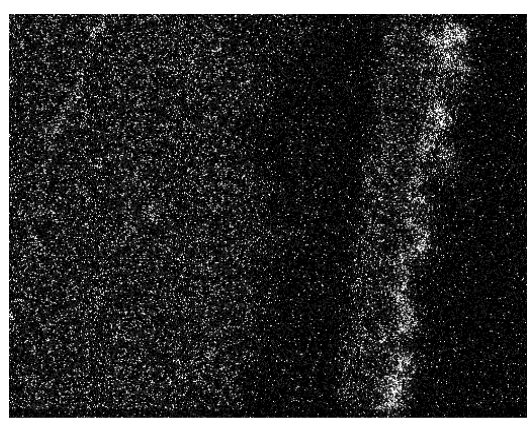

$\mathrm{Ti}$

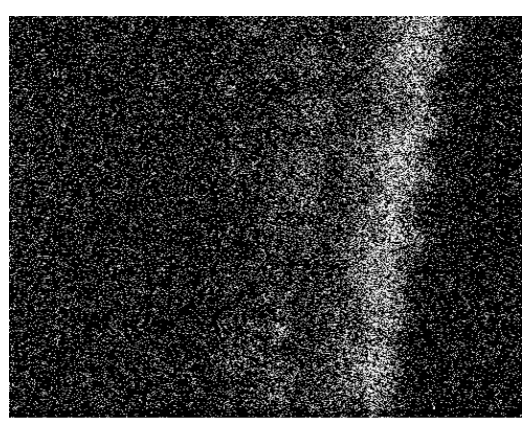

$\mathrm{O}$

Figure 4. SEM image, with Energy Dispersive X-ray Analysis maps, of a section through a Shot-peened CG RR1000 sample held in laboratory air at $800^{\circ} \mathrm{C}$ for 500 hours. 

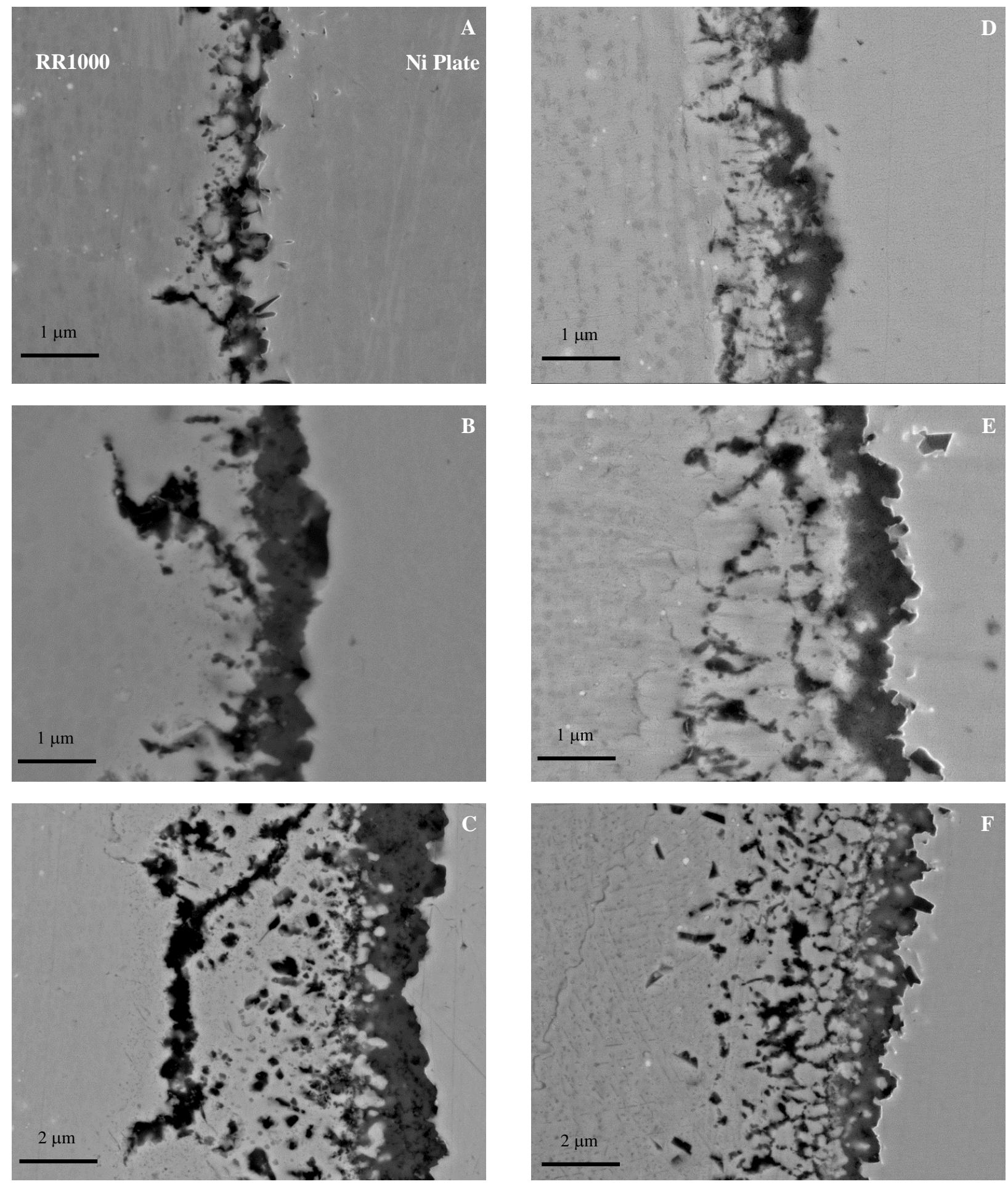

Figure 5. Back-scattered SEM images of sections through samples held at $700^{\circ} \mathrm{C}, 750^{\circ} \mathrm{C}$ and $800^{\circ} \mathrm{C}$ for exposure times of 500 hours $(\mathrm{A}$, D), 1000 hours (B, E) and 500 hours (C, F), without shot-peening (A, B, C) and with shot-peening (D, E, F) showing external and internal oxide formation. 


\section{$\underline{\text { Cross-Sectional Analysis }}$}

Figure 5 shows the oxidation damage at $700^{\circ} \mathrm{C}, 750^{\circ} \mathrm{C}$ and $800^{\circ} \mathrm{C}$, comparing the difference between the two conditions. As can be seen from Figure 4, the surface oxide consists of an outer Ti-rich zone overlying a $\mathrm{Cr}$-rich layer. Under all the test conditions, substantial internal oxidation of $\mathrm{Al}$ had occurred, principally along alloy grain boundaries. This morphology is similar to that reported elsewhere [12] on this alloy in the un-peened condition. At all temperatures, the internal alumina formation appears more extensive in the shot-peened condition. Maximum penetration depths are broadly similar but internal intrusions occur much more frequently in the shot-peened condition, e.g. Figures $5(\mathrm{C})$ and 5(F). The secondary $\gamma^{\prime}$ denuded zone can clearly be seen in Figure 6. Both conditions exhibit a significant secondary $\gamma^{\prime}$ denuded zone that penetrates further into the superalloy than the region of sub-surface alumina formation. This denuded zone is caused by the depletion of aluminum as a result of sub-surface alumina formation.

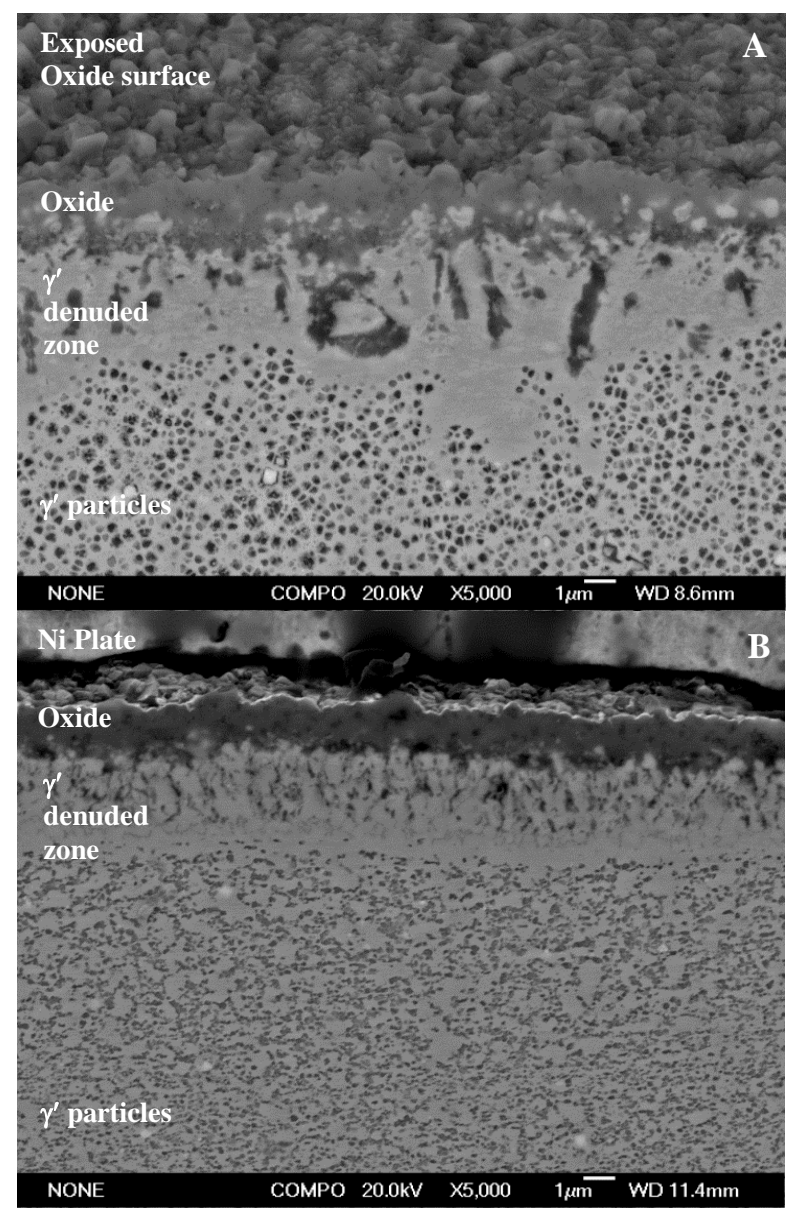

Figure 6. Back-scattered SEM images of sections through CG RR1000 oxidised for 100 hours at $800^{\circ} \mathrm{C}$ showing the $\gamma^{\prime}$ denuded zones in a) the un-peened condition and b) the shotpeened condition.
The depth of the denuded zone in both conditions is similar but has a more planar front in the shot-peened condition. The reason for the more planar front is due to the alumina penetration being more uniformly distributed in the shot-peened samples.

\section{Conclusion}

- Shot-peening of CG RR1000 results in an increase in both surface hardness and roughness as well as causing a shallow region of distorted secondary $\gamma^{\prime}$ particles. Hardness tests show an increased hardness after shot peening extending to $\sim 150 \mu \mathrm{m}$ from the specimen surface.

- Oxidation kinetics are similar in both alloy conditions (shot-peened and un-peened), with shot-peening having an adverse effect on mass gain kinetics at both $700^{\circ} \mathrm{C}$ and $750^{\circ} \mathrm{C}$ but having no significant effect at $800^{\circ} \mathrm{C}$.

- The composition of the oxides formed are similar in both conditions, exhibiting an external oxide scale of $\mathrm{TiO}_{2}$ and $\mathrm{Cr}_{2} \mathrm{O}_{3}$ as well as both conditions exhibiting extensive internal oxidation of aluminium. The shotpeened condition shows more extensive alumina formation. A similar penetration depth was seem in both conditions.

- The depth of secondary $\gamma^{\prime}$ denuded zone was found to be comparable in both specimen conditions, although a more planar front was observed in the shot-peened condition.

\section{Acknowledgements}

The authors acknowledge, with thanks, the support provided by the Engineering and Physical Sciences Research Council (ESPRC) for financial support and Rolls-Royce plc. for further financial support and the provision of samples. We would also like to thank Allan Walton and the Hydrogen group at the University of Birmingham for provision of the confocal microscopy.

\section{References}

ACARE European Aeronautics: A vision for 2020. 2001.

2. E. Andrieu, R. Molins, H. Ghonem, and A. Pineau, Intergranular crack tip oxidation mechanism in a nickel-based superalloy. Materials Science and Engineering: A, 1992. 154(1): p. 21-28.

3. J. Tong, S. Dalby, J. Byrne, M.B. Henderson, and M.C Hardy, Creep, fatigue and oxidation in crack growth in advanced nickel base superalloys. International Journal of Fatigue, 2001. 23(10): p. 897-902.

4. R. Molins, G. Hochstetter, J.C. Chassaigne, and E. Andrieu, Oxidation effects on the fatigue crack growth behaviour of alloy 718 at high temperature. Acta Materialia, 1997. 45(2): p. 663-674.

5. D.M. Knowles and D.W. Hunt, The influence of microstructure and environment on the crack growth 
behavior of Powder Metallurgy nickel superalloy RR1000. Metallurgical and Materials Transactions aPhysical Metallurgy and Materials Science, 2002. 33(10): p. 3165-3172.

J.M. Silva, R.A. Cláudio, C.M. Branco, and J.M. Ferreira, Creep-fatigue behavior of a new generation Ni-base superalloy for aeroengine usage. Procedia Engineering, 2010. 2(1): p. 1865-1875.

7. J. Chen, P. Rogers, and J. Little, Oxidation behavior of several chromia-forming commercial nickel-base superalloys. Oxidation of Metals, 1997. 47(5): p. 381410.

8. J. Evans, Effect of Surface Roughness on the Oxidation Behavior of the Ni-Base Superalloy ME3. Journal of Materials Engineering and Performance, 2010. 19(7): p. 1001-1004.

9. D. Kim, C. Jang, and W. Ryu, Oxidation Characteristics and Oxide Layer Evolution of Alloy 617 and Haynes 230 at $900{ }^{\circ} \mathrm{C}$ and $1100{ }^{\circ} \mathrm{C}$. Oxidation of Metals, 2009. 71(5): p. 271-293.

10. L. Zheng, M. Zhang, and J. Dong, Oxidation behavior and mechanism of powder metallurgy Rene95 nickel based superalloy between 800 and $1000{ }^{\circ} \mathrm{C}$. Applied Surface Science, 2010. 256(24): p. 7510-7515.

11. G.A. Greene and C.C. Finfrock, Oxidation of Inconel 718 in Air at High Temperatures. Oxidation of Metals, 2001. 55(5): p. 505-521.

12. M.P. Taylor, H.E. Evans, S. Stekovic, and M.C. Hardy, The Oxidation Characteristics of the Ni-base Superalloy, RR1000, at Temperatures $700-900^{\circ} \mathrm{C}$, in Microscopy of Oxidation 8 2011: Liverpool.

13. K. Al-hatab, M. Al-bukhaiti, U. Krupp, and M. Kantehm, Cyclic Oxidation Behavior of IN 718 Superalloy in Air at High Temperatures. Oxidation of Metals, 2011. 75(3): p. 209-228.

14. A. Encinas-Oropesa, N.J. Simms, J.R. Nicholls, G.L. Drew, J. Leggett, and M.C. Hardy, Evaluation of oxidation related damage caused to a gas turbine disc alloy between 700 and $800^{\circ} \mathrm{C}$. Materials at High Temperatures, 2009. 26(3): p. 241-249.

15. A. Encinas-Oropesa, G.L. Drew, M.C. Hardy, A.J. Leggett, J.R. Nicholls, and N.J. Simms, Effects of oxidation and hot corrosion in a nickel disc alloy. Superalloys 2008, 2008: p. 609-618.

16. A. Karabela, L.G. Zhao, J. Tong, N.J. Simms, J.R. Nicholls, and M.C. Hardy, Effects of Cyclic Stress and Temperature on Oxidation Damage of a Nickel-Based Superalloy. Materials Science and Engineering: A, 2011. 528(19-20).

17. L. Tan, X. Ren, K. Sridharan, and T.R. Allen, Effect of shot-peening on the oxidation of alloy $800 \mathrm{H}$ exposed to supercritical water and cyclic oxidation. Corrosion Science, 2008. 50(7): p. 2040-2046.

18. D.J. Child, G.D. West, and R.C. Thomson, Assessment of surface hardening effects from shot peening on a Nibased alloy using electron backscatter diffraction techniques. Acta Materialia, 2011. 59(12): p. 48254834.

19. R. Naraparaju, H.J. Christ, F. Renner, and A. Kostka, Effect of Shot-peening on the Oxidation Behaviour of Boiler Steels. Oxidation of Metals, 2011: p. 1-13.

20. G. Petzow, Metallographic Etching. Second ed 2001, Materials Park, $\mathrm{OH}$ : ASM International.

21. Z.W. Huang, H.Y. Li, M. Preuss, M. Karadge, P. Bowen, S. Bray, and G. Baxter, Inertia Friction Welding Dissimilar Nickel-Based Superalloys Alloy 720Li to IN718. Metallurgical and Materials Transactions A, 2007. 38A: p. 1608-1620.

22. H.E. Evans, A.T. Donaldson, and T.C. Gilmour, Mechanisms of breakaway oxidation and application to a chromia-forming steel. Oxidation of Metals, 1999. 52(5-6): p. 379-402. 